\title{
Young Offenders, Serious Crimes
}

\author{
SUSAN BAILEY
}

Violent acts committed by older children and adolescents, and concern about the quality of care and treatment offered to them, have caught the attention of the public and government in the UK.

In England and Wales during the ' 70 s and early '80s there was a move away from a 'nothing works' towards a 'what works' philosophy (Bottoms, 1974; Martinson, 1974). Strenuous and partially successful efforts were made across many agencies to deescalate the juvenile justice process. Many young offenders entered community-based treatment and diversionary programmes (Cawson, 1985). This, together with the welfare principles enshrined in the Children Act 1989, meant that increasingly restrictive criteria had to be satisfied before the imposition of custodial sentences for juveniles.

The Criminal Justice Act 1991 made far reaching changes to the sentencing arrangements of courts in England and Wales. It established a new sentencing framework within which the underlying principle was proportionality in sentencing. For the first time a common framework was applied equally to adults and young offenders but the Act also made important changes in relation to young offenders only, reflecting a further stage in the process of separate treatment for juvenile offenders. The juvenile court in England and Wales, established under the Children Act 1908, became in 1992 the Youth Court, with an extension of the court's jurisdiction, so that instead of dealing with people aged 10 to 16 years inclusive the Youth Court now deals with 17-year-olds. However, the lower age limit for criminal responsibility remains at 10 (in 1992, 20010 - and 11-year-olds were dealt with in the criminal courts).

The main form of custodial sentence for offenders aged 15 to 17 is the Young Offender Institution (YOI), part of the prison service, maximum period of detention limited to 12 months in total. Where a determinate sentence of longer than 12 months is considered necessary for an offender, or where the issue is one of homicide leading to an indeterminate sentence, the young offender is dealt with under Section 53 of the Children and Young Persons Act 1933. Forty per cent of young people held under Section 53 are convicted of murder, manslaughter, arson, rape and wounding but $60 \%$ (approximately 60 youngsters a year) are in fact convicted of robbery and burglary and of these almost all have more than two previous convictions for similar offences. They are what may be described as persistent serious offenders. In 1995, clinicians continue to face the considerable implications of more legislative change. At a time when social services are still in the early stages of implementing Community Care and the Children Act, the Criminal Justice and Public Order Bill 1993 has been implemented and guidance on cautioning reviewed and changed. The three major changes in the sentencing structure for young offenders are:

(i) the Secure Training Order, a sentence for 12- to 14-year-olds available to the Youth and Crown Court; minimum sentence 6 months, maximum 2 years. One-half of a sentence to be served in security in a Secure Training Centre, the second part served in the community under the supervision of social services, the probation or 'other persons' designated by the Secretary of State;

(ii) the maximum sentence of detention in a YOI for 15- to 17-year-olds will increase from 12 months to 2 years;

(iii) a widening of the range of offences for which Section 53 detention can be used to include all youngsters from the age of 10 convicted of offences which carry 14 years or more imprisonment in the case of an adult, and in addition the offence of indecent assault on a woman.

The most disturbed young offenders who commit serious crimes will start their sentence in either local authority community homes (secure care units) or with the Youth Treatment Centre Service, set up by the Department of Health and now well established in two secure centres, Glenthorne and St Charles. In mid-adolescence these youngsters face the difficult transition from care to custody.

\section{Aetiology}

Strong evidence exists for the persistence of severe childhood antisocial behaviour into adolescence and the increased risk it represents for chronic delinquency. Both historically (Burt, 1925) and through recent studies (Farrington, 1990) it has been shown that chronic juvenile delinquency may be amenable to prevention, achieved via early family support and education with recognition of developmental 
vulnerability and resilience, early risk factors and their interactive effects on chronic delinquency; providing support for a cumulative model of delinquency prevention. Conduct disorder (a psychiatric construct) and delinquency (a legal construct) overlap most clearly in the area of chronic delinquency, sharing the characteristic of repeated antisocial behaviour. Prospective cohort studies (Farrington, 1987) have shown that a small group of offenders are responsible for a majority of juvenile crime.

\section{Health profiles}

The nature and extent of psychiatric disturbance in young offenders remains a matter for debate but within the group of serious young of fenders medical conditions should be carefully considered. Common among adolescents who murder is a previous psychiatric contact, antisocial behaviour, history of substance misuse, mental illness within the family and marital conflict. These grave young offenders demonstrate a prominent and wide range of neuropsychological vulnerabilities (Bailey, 1994).

In studies of admissions of serious young offenders to the Youth Treatment Centres (Bullock et al, 1990), a medium secure psychiatric unit (Bailey et al, 1994), and a local authority community home (Hoghughi, 1993), the authors demonstrate high levels of disorder including previous serious suicide attempts. The youngsters had been well known to a range of child agencies prior to admission to secure care and treatment but prominent affective symptoms had not been recognised, the attention of agencies having focused on the aggressive behaviour patterns. Recognition of and subsequent treatment of cooccurring psychiatric disorders, whether affective disorders, psychosis, substance misuse, attention deficit disorder, or learning disability, can form a critical part of an overall multiagency rehabilitation programme to improve general functioning and reduce recidivism (Futterman, 1990).

\section{Treatment in the institutions}

In a comparison of regimes in YOIs, where the emphasis is on custody with clinical intervention as an important secondary goal, and in local authority community homes, where the emphasis is on treatment while maintaining safe secure care, Ditchfield \& Catan (1992) found that offenders released from community homes did better in terms of reconviction than those from YOIs and this was at least partly attributable to differences in their regimes. Treatment models in all types of secure care cover the full range of psychotherapeutic and behaviour modification programmes. However, there are core general factors that cut across theoretical orientations and are associated with better outcomes. These factors include good leadership, good discipline, special education, an active work and recreation programme, positive adolescent-adolescent, staff-adolescent and staff-staff relations, together with a milieu that provides a sense of warmth and harmony and that has organisation, practicality and high expectations (Harris et al, 1987).

In a long-term outcome study of 204 leavers from the Youth Treatment Centres (one offering a psychotherapeutic programme, the other adhering to principles of social learning) Bullock et al (1994) showed that the other key factor to good outcome was the ability to enable the young person to look at his or her own family life, and wherever possible to involve the family in treatment.

In the YOIs the picture is complex (Little, 1990). Rehabilitation programmes are undertaken in the context of other negative processes. In the social milieu of prison, young of fenders with aggressive, impulsive, depressive and dependency problems engage in discussion of suicide, ideation of escape and relief from the environment. Self-injury can be perceived as an act of rebellion against a perceived controlling and aggressive system. Positively there has been increasing recognition of the importance of such factors within the prison setting (Waplington, 1994).

\section{Individual therapies}

Social skills programmes have focused on microskills such as eye contact, body posture and tone of voice, and macro skills such as avoiding fighting within institutions. These have led to changes in institutional performance but with less certainty about a reduction in future offending. More promising are the changes that can be brought about by cognitive-behavioural programmes, in particular multi-model programmes incorporating the elements of self-control and selfinstruction, anger control, role taking, social problem solving and programmes devised to increase the young offenders' moral reasoning ability (Hollin, 1993).

The use of psychotherapy for grave offenders can be an important adjunctive treatment. The capacity to form emotional attachments with others and an ability for self-examination and insight are positive indicators for such intervention. Therapeutic gains emerge slowly given the often chaotic and abusive backgrounds of the young of fenders, and severe past aggression, low intelligence and poor capacity for insight are associated with poor outcome (Myers, 1992).

The use of cognitive-behavioural psychotherapy, in the setting of an institution offering healthy role models, consistent limit setting, education and 
vocational training, continued liaison and involvement of family, offers a way forward to provide a safe development into adult life and minimise future risk.

While others debate the issues of whether those children facing charges of murder, manslaughter or attempted murder should be locked up, whether treatment is worthwhile, what their rights are and how these balance against those of the victim and victim's family, whether we have adequate legal and administrative procedures, and finally what the appropriate interventions post-trial may be, the individual clinician and immediate responsible carers have to set about the long-term task of rehabilitation. Outside pressures will inevitably continue to wax and wane. The therapist, while engaged in treatment with the young offender, has to be mindful of the role he or she may be asked to take in the decision-making process concerning future risk, and the offenders' perception of the therapist as someone who may influence "time served'. The majority of child and young adolescent offenders initially dissociate themselves from the reality of their offence and situation; but dependent on their own stage of emotional and psychological development most will start to engage in treatment, whether via verbal or non-verbal therapies (Aulich, 1994).

Treatment focusing on the violent and/or sexual aspects of their offence and the bearing this has on their own personality development and future risk has to be visited and revisited, as their own emotional and psychological capacity to deal safely with it emerges. The baggage of history that accompanies these older children and adolescents - depositions, newspaper cuttings, day-to-day observations from carers, peers and family - can be used as therapeutic tools. This process needs to continue with consistency of therapy and therapists as they move from secure care to penal establishment.

\section{Conclusion}

The antecedent histories of serious young offenders have highlighted the failure of previous interventions. Offenders with similar problem and offending careers have drifted within and between the four jurisdictions of special education, health, care and criminal justice.

As pointed out by Lipsey (1992) rehabilitation programmes do not succeed where there is client or institutional resistance. Any programme regardless of theoretical base has to be vigorously and properly implemented with planning for content, resources and trained staff that can undertake assessment and move onto a programme that has treatment integrity.

\section{References}

AuLich, L. (1994) Fear and loathing; art therapy, sex offenders and gender. In Art Therapy with Offenders (ed. M. Liebmann), pp. 165-197. London: Jessica Kingsley.

Balley, S. (1994) Critical Pathways of Child and Adolescent Murderers. Chronicle of the International Association of Juvenile and Family Court Magistrates, 1(3), 5-12.

, Thornton, L. \& Weaver, A. B. (1994) The first 100 admissions to an Adolescent secure unit. Journal of Adolescence, 17, 001-013.

Botroms, A. E. (1974) On the decriminalisation of the English Juvenile Court. In Crime, Criminology and Public Policy (ed. R. Hood). London: Heinemann.

Bullock, R., Hosie, K., Little, M., et al (1990) Secure accommodation for very difficult adolescents: some recent research findings. Journal of Adolescence, 13, 205-216.

-, Little, M. \& Millham, S. (1994) The Part Played by Career, Individual Circumstance and Treatment Interventions in the Outcomes of Leavers from the Youth Treatment Centres. Dartington: Dartington Social Research Unit.

BURT, C. (1925) The Young Delinquent. London: University of London Press.

Cawson, P. (1985) Intermediate treatment. Journal of Child Psychology and Psychiatry, 26, 675-681.

Ditchfield, J. \& CATAN, L. C. (1992) Juveniles sentenced for serious offences: a comparison of regimes in Young Offender Institutions and local authority community homes. Research and Planning Unit. Paper 66. Home Office.

Farkington, D. P. (1987) Early precursors of frequent of fending. In From Children to Citizens: Families, Schools and Delinquency Prevention (eds J. Q. Wilson \& G. C. Loury), pp. 27-50. New York: Springer Verlag.

- (1990) Implications of criminal career research for the prevention of offending. Journal of Adolescence, 13, 93-113.

Futterman, E. H. (1990) The psychiatrist and the juvenile justice system. American Journal of Psychiatry, 174, 1584-1586.

Harris, D. P., Cole, J. E. \& Vipond, E. M. (1987) Residential treatment of disturbed delinquents. Description of a centre and identification of therapeutic factors. Canadian Journal of Psychiatry, 32, 579-583.

Hogrughi, M. (1993) Young People at the Margins - an Aycliffe Profile. Aycliffe, Durham: Centre for Adolescent Studies.

Hollin, C. (1993) Advances in the psychological treatment of delinquent behaviour. Criminal Behaviour and Mental Health, 3, 142-157.

LIPSEY, M. W. (1992) Juvenile delinquency treatment: a metaanalytic inquiry into the variability of effects. In Meta-analysis for Explanation: A Casebook (eds T. D. Cook, H. Cooper, D. S. Cordray, et al), pp. 83-127. New York: Russell Sage Foundation.

LITTLE, M. (1990) Young men in prison. Dartmouth: Aldershot.

MARTinson, R. (1974) What works? - questions and answers about prison reform. The Public Interest, 10, 22-54.

Myers, C. (1992) What treatment do we have for children and adolescents who have killed. Bulletin of the American Academy of Psychiatry and the Law, 20, No. 1.

WAPLINGTON, D. (1994) Understanding adolescents - A key concept in constructing the regime for young of fenders at $\mathrm{HM}$ YOI Lancaster Farms. Prison Service Journal, 96.

Dr Susan Bailey, Adolescent Forensic Service, Mental Health Services, Bury New Road, Prestwich, Manchester M25 3BL

(First received 8 August 1994, final revision 9 January 1995, accepted 7 February 1995) 